\title{
Stigma and Cystic Fibrosis
}

\author{
Tainá Maues Peluci Pizzignacco ${ }^{1}$ \\ Débora Falleiros de Mello² \\ Regina Aparecida Garcia de Lima $^{3}$
}

\begin{abstract}
Cystic Fibrosis (CF), also known as Mucoviscidosis, is a chronic disease of autosomal recessive origin and so far incurable. This analysis considers some characteristics of patients and family members that indicate it is a stigmatizing disease. The CF stigma's impact on the lives of children and adolescents can affect treatment adherence, socialization, family relationships and the formation of their life histories, with direct consequences on their quality of life.
\end{abstract}

Descriptors: Cystic Fibrosis; Stereotyping; Family; Socialization; Pediatric Nursing.

Escola de Enfermagem de Ribeirão Preto, Universidade de São Paulo, WHO Collaborating Centre for Nursing Research Development, Brazil:

${ }^{1}$ RN, M.Sc. in Nursing, e-mail: tainapizzi@usp.br.

2 RN, Associate Professor, e-mail: defmello@eerp.usp.br.

${ }^{3} \mathrm{RN}$, Full Professor, e-mail: limare@eerp.usp.br.

Corresponding Author:

Tainá Maués Pelúcio Pizzignacco

Rodovia Antonio Machado Santannam Km 3,8 Casa 13

Jd dos Hibiscos

CEP: 14022-310 Riberão Preto, SP, Brasil

E-mail: tainapizzi@usp.br 


\section{Estigma e fibrose cística}

A fibrose cística (FC), também conhecida como mucoviscidose, é doença crônica de origem autossômica recessiva e, até o momento, incurável. A presente reflexão traz considerações a respeito de algumas características que acompanham pacientes e familiares, permitindo compreendê-la como doença estigmatizante. As repercussões do estigma na vida de crianças e adolescentes com FC podem implicar na adesão ao tratamento, no processo de socialização, na relação com os familiares e na formação de sua biografia, com reflexo direto em sua qualidade de vida.

Descritores: Fibrose Cística; Estereotipagem; Família; Socialização; Enfermagem Pediátrica.

\section{Estigma y fibrosis cística}

La fibrosis cística (FC), también conocida como mucoviscidosis, es una enfermedad crónica de origen autosómica recesiva y, hasta el momento, incurable. La presente reflexión presenta consideraciones a respecto de algunas características que acompañan a pacientes y familiares, permitiendo comprenderla como enfermedad que estigmatiza. Las repercusiones del estigma en la vida de niños y adolescentes con FC pueden interferir en la adhesión al tratamiento, en el proceso de socialización, en la relación con los familiares y en la formación de su biografía, con reflejo directo en la calidad de vida.

Descriptores: Fibrosis Quística; Estereotipo; Familia; Socialización; Enfermería Pediátrica.

\section{Introduction}

Cystic fibrosis (CF) is the inherited chronic disease most common among Caucasians ${ }^{(1)}$ and affects one in every 2,500 Europeans, with a similar incidence in

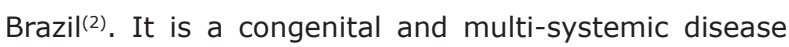
that affects the mucus production of exocrine glands, which become thick and obstruct the channels in which it is secreted ${ }^{(1)}$. This manifestation can occur in numerous epithelial cells including sweat, pancreatic and bile ducts, airways, intestinal and deferent vessels ${ }^{(3)}$.

There are several clinic manifestations due to the CF genetic characteristic with more than 1,000 acknowledged mutations so far, though there is always a triad of symptoms in the pulmonary and digestive tracts and in the sweat glands ${ }^{(1)}$.

The treatment has to be delivered several times a day ${ }^{(4)}$. The possibility of treating patients at home allows them to go places and perform tasks common to people in the same age group(5).

The CF can be considered a stigmatizing disease because it marks those who live with it. There is body deformity caused by the evolution of the disease, which marks the body in a characteristic way, including producing a barrel chest and clubbing of the feet.
Additionally, there are daily and constant care rituals, which oftentimes impede children and adolescents from performing activities common to their age group ${ }^{(6)}$.

\section{Considerations of stigma}

We understand that stigma is a situation in which the individual is not fully socially accepted. This term was created by the Greeks to indicate something bad in the moral status of those who were stigmatized and is translated as a bodily mark. It is profoundly depreciatory and distinguishes an individual from others who are in a certain social category(7).

There are three types of stigma: the body stigma, moral and tribal race stigma and that of nation or religion. The majority can be immediately perceived through an individual's stereotype, which causes the individual to become discredited, while other types of stigma can be hidden and are not perceptible in a first contact, which causes the individual to become discreditable. This difference is crucial to the way one copes with stigma(7).

A stigma is based on differences, that is, on 
what is considered normal and on what is considered deviant or pathological. In addition to the individual who possesses stigmatizing characteristics, people close to him/her, such as relatives and friends, share the stigma, a concept referred to as courtesy stigma. The roots of body patterns are socially constructed and fixed in and through children's education and socialization processes $^{(7)}$.

\section{Cystic Fibrosis: a Stigmatizing Disease}

The impact of the stigma related to CF is especially critical during childhood and adolescence because these are periods when social relationships and the individuals' identity are formed.

Because CF is a congenital disease and is most often diagnosed during childhood, many children with CF start to quantify their differences. For example, they realize, only by being in contact with their peers, that they are smaller and thinner than their peers, that they cough and become tired more easily, and thus the school environment is frequently the landmark of their experience with their chronic disease ${ }^{(5,8-10)}$.

Physical differences are not the only reason children with CF become stigmatized. The differences in these children's daily routine caused by the disease symptoms and treatment also contribute to making them different and consequently stigmatized(9-11).

Children with CF can become confused by the way their peers respond to their differences and do not understand the meaning others attribute to the disease symptoms. The fear of not being accepted leads to anxiety and fear of social interactions ${ }^{(10)}$.

Although stigma and being transmittable are distinct concepts, they come together in the case of disease and the stigma is seen as something contagious and the contagion as something stigmatizing. This union of concepts highlights that the social course of the disease can result from its biological course, thus, one notion reinforces the other ${ }^{(12)}$.

Even though CF is not a transmissible disease, it can have the same impact, as if it was transmittable, in mixed contacts. The fact that the disease has a visible symptomatology, such a cough and expectoration, has an immediate impact on interpersonal relationships and is related to the issue of being transmittable, reinforcing shame and fear of $\operatorname{stigma}^{(9,11)}$.

One of the ways used to minimize the stigma associated with the disease is concealment ${ }^{(7)}$. Some studies $^{(6,9-10)}$ have shown that oftentimes disclosing the disease, which is seen as a secret, is reserved only for those closest, such as best friends.

Circumventing the treatment is not only a way to avoid other people learning about the disease but also a way to forget, for a while, that the disease exists. It is a way of normification ${ }^{(5,11)}$

The differences related to CF can lead, especially for adolescents, to seek new bases of comparison and closeness among those that share the stigma(1,13). In addition to helping to reduce the perception of being different, meeting other people with CF makes them feel less lonely and share experiences( ${ }^{(8)}$.

The formation and search for groups of people who share a stigma is one of the available means of coping with stigma. Studies show that sharing information, feelings, concerns and even similar characteristics of people with CF and their family members is one of the social supports most expected and significant for these people(11,14).

Families of children and adolescents with CF also share the feeling of being different when they compare their lives with those of other families with healthy children ${ }^{(8)}$. This feeling was described in studies with families of children with chronic diseases, such as those dependent on mechanical ventilation at home ${ }^{(15)}$.

In addition to children and adolescents with $\mathrm{CF}_{\text {, }}$ their families can also become socially isolated due to the constant care they have to deliver to their children ${ }^{(14)}$, which causes distancing from other social functions such as work $^{(16)}$.

\section{Final Considerations}

Cystic fibrosis is considered a stigmatizing disease by those who have it and their families. For this reason, it affects different spheres of social life because it is a sociocultural construct. The repercussions of stigma in the lives of children and adolescents with CF can affect treatment adherence, socialization, relationships with family members and the formation of their life histories, directly impacting their quality of life.

Similar results were found in a study of adolescents with HIV/AIDS ${ }^{(16)}$, which corroborates the considerations presented here, that knowledge of the disease stigma is relevant to plan care, evaluation of treatment adherence and to promoting quality of life of children and adolescents with chronic diseases. 


\section{References}

1. Davis PB. Cystic fibrosis since 1938. Am J Respir Crit Care Med 2006; 173:475-82.

2. Ribeiro DJ, Ribeiro MAGO, Ribeiro AF. Controvérsias na fibrose cística: do pediatra ao especialista. J Pediatr (Rio de Janeiro) 2002; 78(8):171-86.

3. Anferson M. The school-age child with cystic fibrosis. J Sch Health $1980 ; 50(1): 26-8$.

4. Gjengedal E, Rustøen T, Wahl AK, Hanestad BR. Growing up and living with cystic fibrosis. ANS Adv Nurs Sci 2003; 26(2):149-59.

5. Foster C, Eiser C, Oades P, Sheldon C, Tripp J, Goldman P, et al. Treatment demands and differential treatment of patients with cystic fibrosis and their siblings: patient, parent and sibling accounts. Child: Care, Heath and Develop 2001; 27(4):349-64. 6. Pizzignacco TMP, Lima RAG. Socialization of children and adolescents with cystic fibrosis: a support for nursing care. Rev Latino-am Enfermagem 2006; 14(4):569-77.

7. Goffman E. Estigma: notas sobre a manipulação da identidade deteriorada. $4^{\circ}$ ed. Rio de Janeiro: LTC; 1988.

8. D'auria JP, Christian BJ, Richardson LF. Through the looking glass: children's perception of growing up with cystic fibrosis. Can J Nurs Res 1997; 29(4):99-112.

9. D'auria JP, Christian BJ, Henderson ZG. The company they keep the influence of peers relationships on adjustment to cystic fibrosis during adolescence. J Pediatr Nurs 2000; 15(3):175-82. 10. Badlan K. Young people living with cystic fibrosis: an insight into their subjective experience. Health Soc Care Commun 2006; 143):262-70.

11. Christian BJ, D'auria JP. The child's eye: memories of growing up with cystic fibrosis. J Pediatr Nurs 1997; 12(1):3-12.

12. Das V. Stigma, contagion, defect: issues in the anthropology of public heath. Stigma and global health: developing a research agenda conference [on line] 2001 September [Acess 2007 March 7]; Available from: http://www.stigmaconference.nih. gov/finalDaspaper.htm.

13. Hodgkinson $R$, Lester $H$. Stresses and coping strategies of mothers living with a child with cystic fibrosis: implication for nursing professionals. J Adv Nurs 2002; 39(4):377-83.

14. Furtado MCC, Lima RAG. O cotidiano da família com filhos portadores de fibrose cística: subsídios para o cuidado de enfermagem. Rev Latino-am Enfermagem 2003; 11(4):444-52.

15. Carnevale FA. Revisiting Goffman's stigma: the social experience of families with children requiring mechanical ventilation at home. J Child Heath Care 2007; 11(1):7-18.

16. Lima AMA, Pedro ENR. Growing up with HIV/AIDS: a study on adolescents with HIV/AIDS and their family caregivers. Rev Latino-am Enfermagem 2008 maio-junho; 16(3):348-54. 